Original Research Paper

\title{
Recycle of Plastic Bag Wastes with Organic Wastes to Energy for RDF Productions
}

\author{
Rithy Kan, Chatchai Kungkajit and Thaniya Kaosol \\ Department of Civil Engineering, Faculty of Engineering, \\ Prince of Songkla University, Songhkla, Thailand
}

\author{
Article history \\ Received: 7-7-2017 \\ Revised: 28-08-2017 \\ Accepted: 13-12-2017 \\ Corresponding Author: \\ Thaniya Kaosol, \\ Prince of Songkla University, \\ Songkhla, Thailand \\ Email: thaniya.k@psu.ac.th
}

\begin{abstract}
This paper studies the utilization potential of Refuse Derived Fuel (RDF) approach to recover the discarded plastics from Hatyai solid waste disposal site in Songkhla province, Thailand. The excavated plastic bag wastes from the closure landfill of Hatyai, unused plastic bag wastes and waste residues are the raw materials for RDF productions. The raw materials are characterized for proximate analysis and ultimate analysis. The RDF5 (Densified RDF) with different raw materials are produced and characterized in this study. All raw materials have low moisture content, high volatile solids, low ash content and low fixed carbon. Thus, these raw materials are suitable for RDF productions. Due to low sulfur content, the combustion of these RDFs has no risk for the global warming and acid rain cause. The various RDFs in this study include a plastic bag wastes-palm fronds-RDF (PP-RDF), an unused plastic bag wastes-palm fronds-RDF (UPP-RDF), a plastic bag wastes-palm fronds-cassava peels-RDF (PPCRDF) and a plastic bag wastes-palm leaves-rubber wastes-RDF (PPRRDF). The various RDFs are provided the good physical and chemical properties. The higher heating value (HHV) of PP-RDF, UPP-RDF, PPCRDF and PPR-RDF is $5,725,5,674,5,548$ and $5,872 \mathrm{kcal} / \mathrm{kg}$, respectively. The HHV of various RDFs is higher than the HHV criterion for RDF in the briquette form. Therefore, the plastic-wastes RDF has the potential for energy as solid fuels for kiln. According to this study, the plastic-bagwastes RDF in the briquette form is suitable for renewable energy.
\end{abstract}

Keywords: RDF, Plastic Bag, Energy, HHV, Briquette

\section{Introduction}

Generally, the municipal solid wastes are difficult to manage because they are not homogenous, which can rise to fluctuations in composition and quality (Murphy and McKeogh, 2004). Landfill with its many drawbacks is the preferred option in Thailand. The composition of excavated wastes from the Hatyai's dumpsite shows high plastic wastes content of total weight (15 to $20 \%$ ). Plastic has become the common materials since the beginning of the 20th century for the modern life. It is used to manufacture everyday products such as toys, packaging, containers, appliances, nondurable goods and furniture. The widespread use of plastics demands a proper management of plastic waste as well (Arena et al., 2003; Tue and Thwe, 2013). The plastic bag is the major excavated plastic bag waste found. The plastic is not a natural product thus the nature of plastic has no way to break it down. The plastic bag waste is a widely recognized source of pollution because the plastic bag wastes are not chemical additives. Some of them can migrate into the body tissue and enter the food chain. Energy recovery from waste can be an economically attractive source of energy as part of an integrated solid waste management plan (Beccali et al., 2001; Koukouzas et al., 2008; Al-Salem et al., 2009; Arena et al., 2011; Saifuddin et al., 2016). The energy conversion technology of plastic wastes, especially the pyrolysis and gasification technologies have been studied to promote the renewable energy utilization and solve the environmental pollution (Gug et al., 2015).

Refuse Derived Fuel (RDF) is produced from combustible components of municipal solid waste (Piao et al., 1998; Caputo and Pelagagge, 2002; Gendebien et al., 2003; Rotter et al., 2004; UNEP, 2005; Weber et al., 2009). The waste is shredded, dried and baled and then burned to produce electricity (Consonni et al., 2005). In Thailand, the RDF productions are created to divert combustible 
fraction from municipal solid wastes in order to produce the solid fuel and then to be used as the substitution energy for many industries.

During the briquette RDF production phase, it is very difficult to obtain a strong briquette by cool piston compression from plastic wastes without a binder. Typical binders are sawdust, pitch, limestone, oily organic wastes, fibrous wastes, starch and residue wastes (Yaman et al., 2001). In Thailand, the RDF productions are designed to divert combustible fraction from municipal solid wastes to produce solid fuel and then to be used as substitution energy for many industries. However, there is no RDF production plant in Thailand due to lack of information for investors and decision makers. Moreover, RDF can be served as supplementary solid fuel for specific types of industries. In this regard, RDF utilization can be considered as Clean Development Mechanism (CDM) and conforms to Kyoto Protocol (Koukouzas et al., 2008). The RDF production and utilization can positively contribute to local and global environments. The plastic waste RDF becomes one of the interesting alternatives to solve both of the global warming and municipal solid waste management problems. Its advantages are not only to improve global environmental quality, but also decrease local economic loss. The excavated plastic waste RDF has higher calorific value, higher heating value and more consistency in quality. The excavated plastic waste from the closure landfill needed to be separated from the other wastes for producing the RDF.

This paper aims to investigate the use of various binders as a glue to produce a RDF from plastic bag wastes for kiln fuels. The proximate analysis and ultimate analysis are investigated for various RDF productions in the briquette form.

\section{Materials and Methods}

\section{Raw Materials for RDF Production}

The excavated plastic waste is the plastic bag waste from the closure landfill from Hatyai's landfill, southern of Thailand. After excavation, the plastic bag wastes are separated from soil, grit, sand and other wastes using trammel screen or rotary drum screen (Fig. 1a). The excavated plastic bag wastes need to be cut to reduce the size. The chopped plastic bag wastes are $3.0-5.0 \mathrm{~cm}$ in length (Fig. 1b). After the size reduction, they cannot be compacted alone due to the lack of glue in plastic wastes. Some binders are needed. In this experiment, the binders for RDF productions are the palm fronds and rubber wastes. The unused plastic wastes are prepared from the new plastic bag (Fig. 2a) and cut to reduce the size (Fig. 2b). The fresh palm fronds are collected from the palm plantations in southern of Thailand as an agricultural residue (Fig. 3a) and chopped to reduce the size (Fig. 4). The size of fresh palm frond is $5-7 \mathrm{~cm}$ in length. Then, they are dried by sunshine and wind before the compaction process (Fig. 3b).

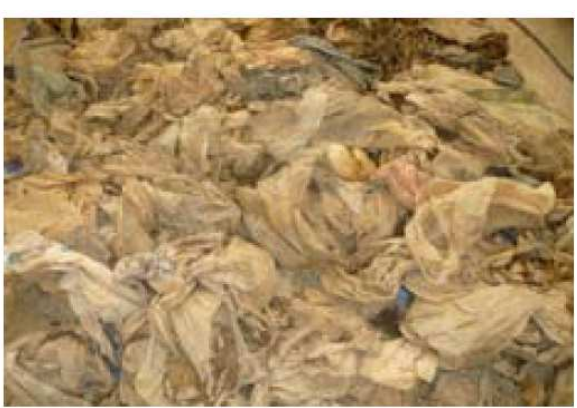

(a)

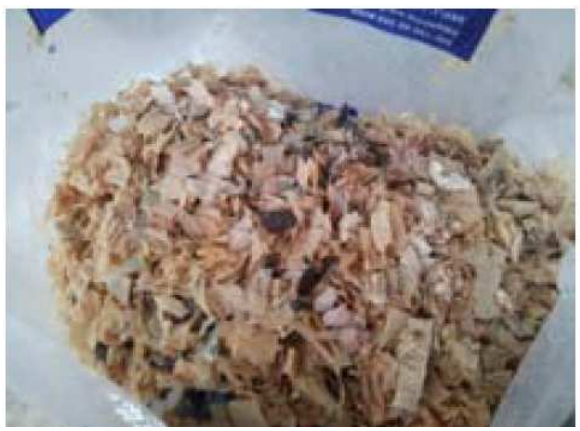

(b)

Figs. 1: (a) Excavated plastic bags from the closure landfill and (b) excavated plastic bags after size reduction

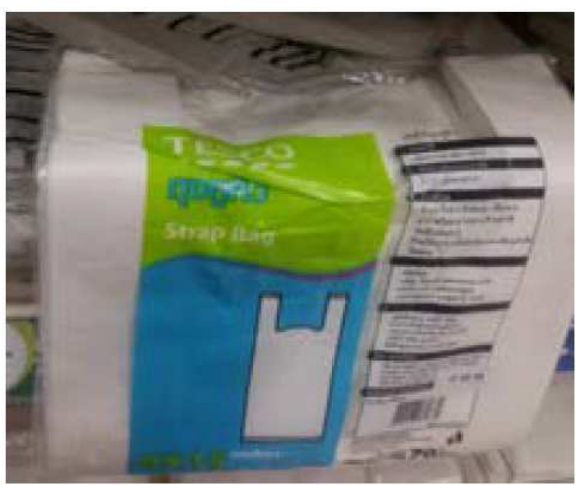

(a)

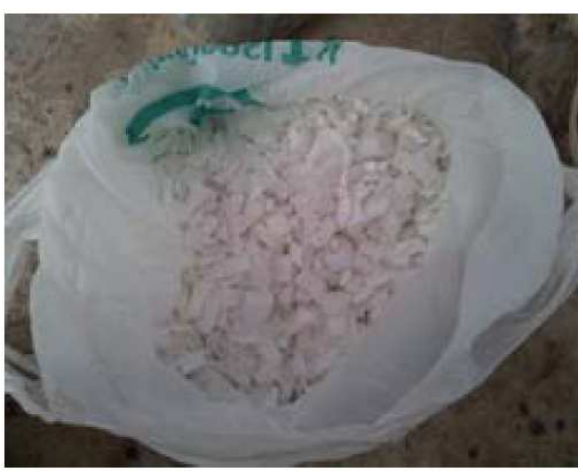

(b)

Figs. 2: (a) Unused plastic bags and (b) unused plastic bags after size reduction 


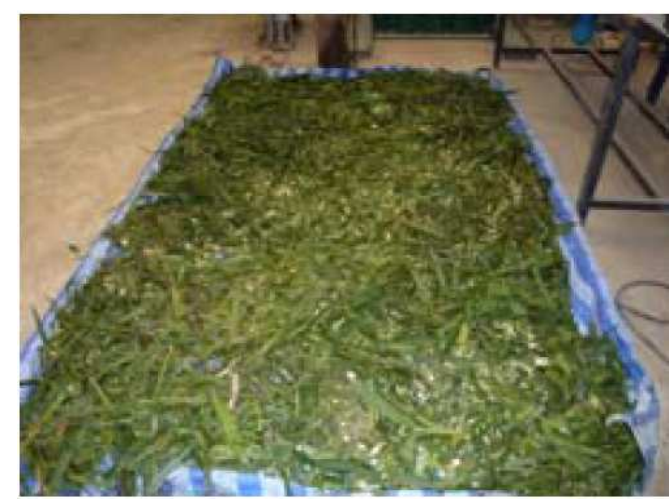

(a)

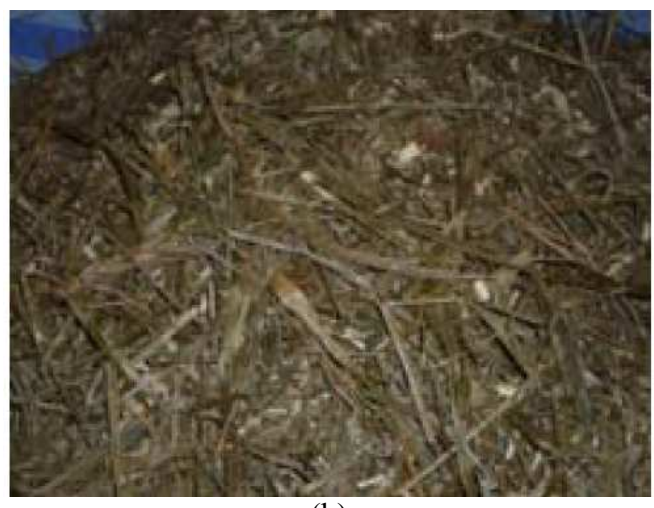

(b)

Fig. 3: (a) Fresh palm fronds after size reduction and (b) dry palm fronds after size reduction

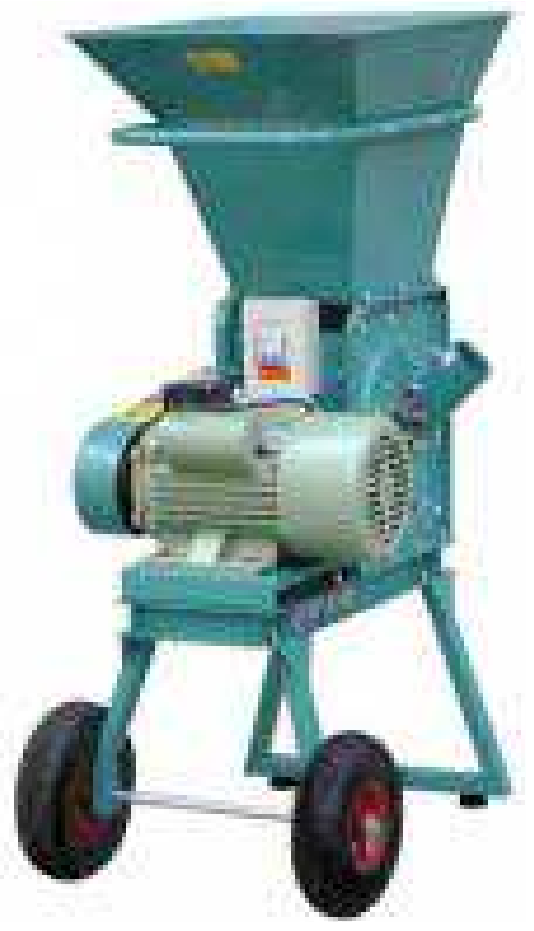

Fig. 4: Fresh palm frond crusher

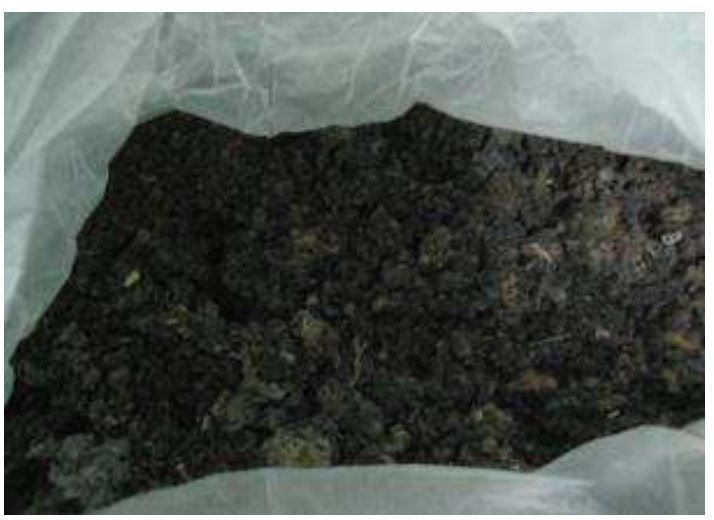

(a)

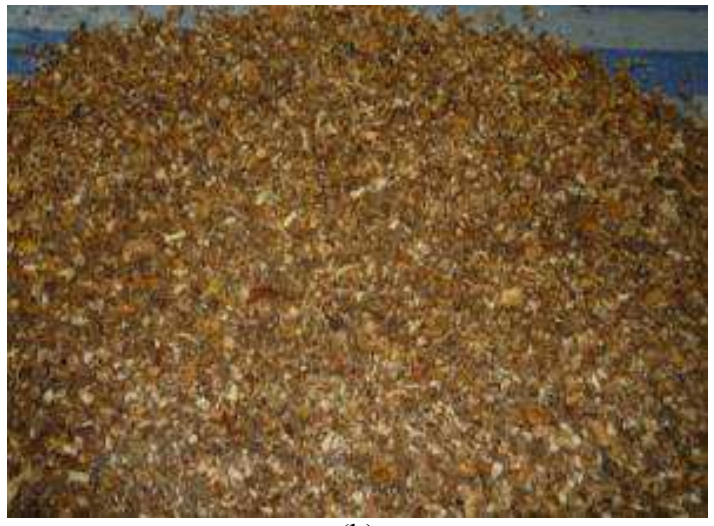

(b)

Figs. 5: (a) Fresh palm fronds after size reduction and (b) dry palm fronds after size reduction

The rubber wastes are collected from the rubber factory in Hatyai city, Songkhla province, southern of Thailand (Fig. 5a). They are chopped for the size reduction and dried before the RDF productions. The cassava peels are collected from the Hatyai's market in Hatyai city, southern of Thailand (Fig. 5b). They are chopped for the size reduction and dried before the productions. After the size reduction, all raw materials are analyzed to find their physical and chemical properties.

\section{RDF Productions}

The used and unused plastic bags are the main raw materials for RDF productions. The plastic bag waste RDF becomes one of the attractive alternatives (wasteto-energy) to solve both the global warming and municipal solid waste management problems. The RDF type in these experiments is RDF-5 which is the densified (compressed) combustible wastes in the forms of pellets, slugs, cuvettes or briquettes, namely "Densified RDF" (ASTM, 2006). The excavated plastic wastes and unused-plastic wastes were shredded and blended with cassava peel, rubber waste and palm leaves in a proportionate ratio to produce RDF mainly targeted for kiln fuel. 


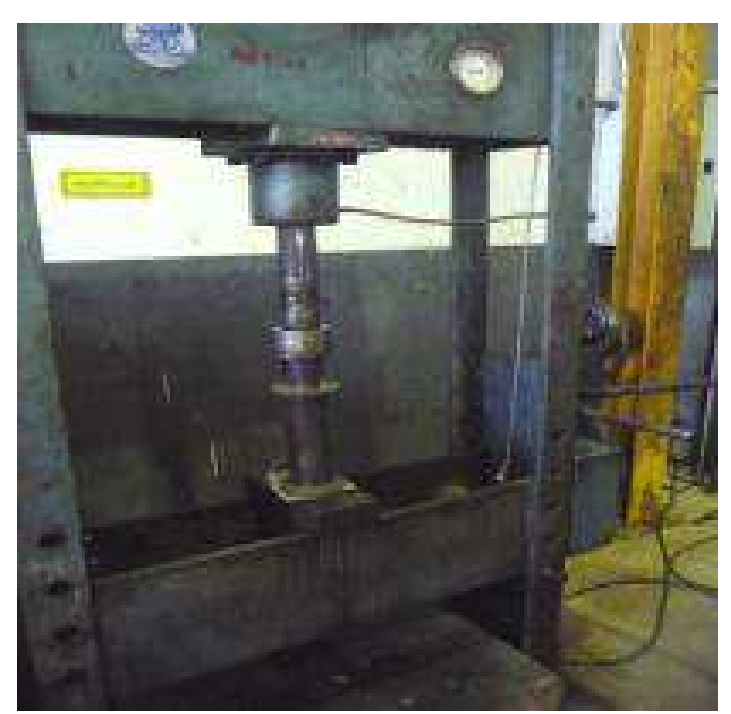

(a)

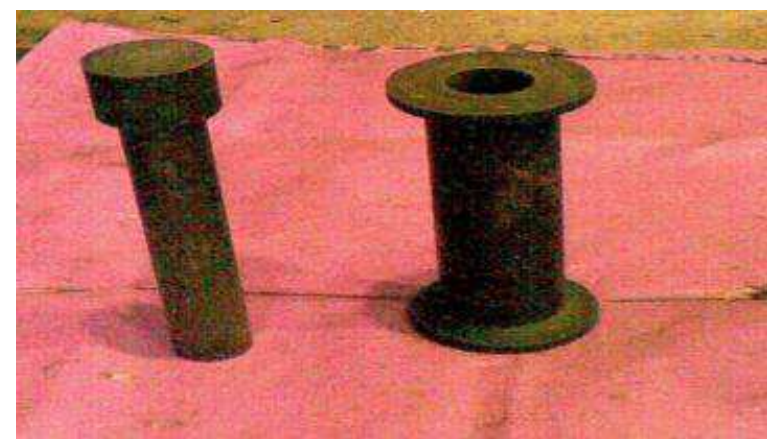

(b)

Figs. 6: (a) The RDF compactor and (b) the equipment for RDF productions

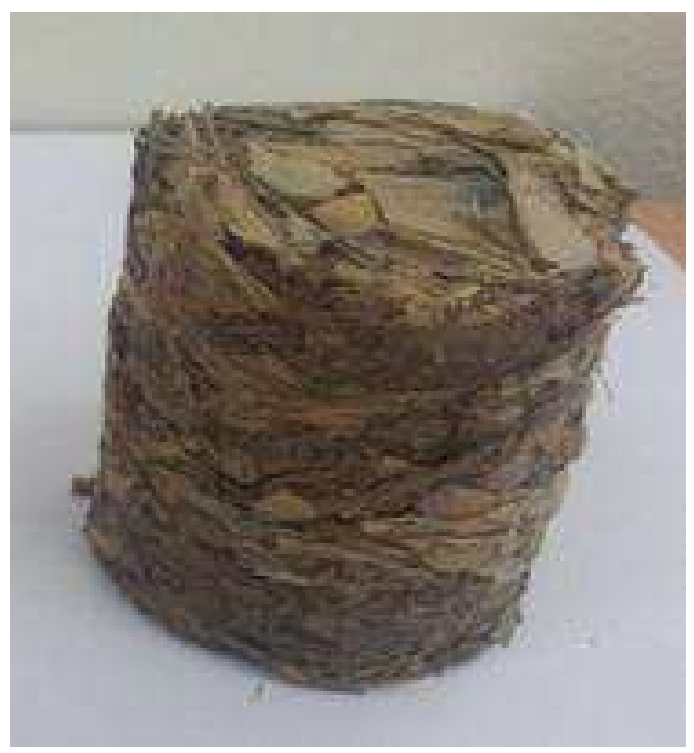

Fig. 7: The RDF from excavated plastic bags, palm fronds and rubber wastes
All raw materials are well mixed at the weight mixing ratio of 1:1.5 (plastic wastes: binder). These are then formed into briquettes using a cool piston compression with $5 \mathrm{~cm}$ in diameter and 6-7cm in height (Figs. 6 and 7). The various RDFs are analyzed for proximate analysis and ultimate analysis.

\section{Results and Discussions}

\section{Raw Material Properties}

The results of raw materials characteristics are shown in Table 1. Five raw materials are excavated plastic bag wastes, unused plastic bag wastes, palm fronds, rubber wastes and cassava peels. The palm fronds, rubber wastes and cassava peels are the binder as glue for RDF5 productions in these experiments. All raw materials have low moisture content. They are suitable for RDF productions. The volatile solids of excavated plastic bag wastes, unused plastic bag wastes, palm fronds and rubber wastes are $89.12 \%, 88.78 \%, 95.92 \%$ and $99.20 \%$, respectively. The highest volatile solid was found in rubber wastes. The volatile solids of raw materials are very high, while the fixed carbon and ash are very low. Therefore, the ash residues are low. The solid residues will be easily for final disposal. These results supported their use in energy recovery process provided that the environmental impact such as air pollution increasing from their utilization in the thermal processing could be effectively controlled through limiting of harmful substances in wastes. The primary concern of RDF utilization for thermal conversion process was their sulfur and chlorine contents. The sulfur content of excavated plastic bag wastes, unused plastic bag wastes, palm fronds and rubber wastes are $0.07 \%,<0.01 \%$, $0.21 \%$ and $0.04 \%$, respectively. They have very low sulfur content. Thus, they have no risk for the global warming and acid rain cause.

The calorific value of raw materials of excavated plastic bag wastes, unused plastic bag wastes, palm fronds and rubber wastes is 38,694, 39,980, 15,714, 43,156 and $14,085 \mathrm{~kJ} / \mathrm{kg}$, respectively. The calorific value of excavated plastic bag wastes, unused plastic bag wastes and rubber wastes is higher than that of palm fronds and cassava peel. These calorific values of excavated plastic bag wastes and unused plastic bag wastes are concurring with the typical value for plastic bag wastes $(28,000-37,000 \mathrm{~kJ} / \mathrm{kg})$ reported in Tchobanoglous et al. (1993). Ultimate analysis of raw materials is tabulated in Table 1.

The majority content of the raw materials is carbon content $(>40 \%)$. Since the plastic is the petroleum derived product (hydrocarbon compound), the carbon and hydrogen contents are the major elements. The excavated plastic bag wastes and unused plastic bag wastes have the larger amount of carbon, leading to the higher calorific value in comparison with the remaining biomass. 
Table 1: Raw material characterizations

\begin{tabular}{llllll}
\hline Parameters & Excavated plastic bag & Unused plastic bag & Palm fronds & Rubber wastes & Cassava peels \\
\hline 1. Proximate analysis & & & & & \\
$1.1 \mathrm{MC}(\%)$ & 0.01 & 0 & 0.40 & 0.03 & 0.49 \\
$1.2 \mathrm{VS}(\%)$ & 89.12 & 88.78 & 95.91 & 99.20 & 94.92 \\
$1.3 \mathrm{FC} \mathrm{( \% )}$ & 0.66 & 0.42 & 0 & 0.15 & 0 \\
1.4 Ash (\%) & 10.21 & 10.79 & 4.06 & 0.62 & 4.71 \\
2. Ultimate analysis & & & & \\
$2.1 \mathrm{C} \mathrm{( \% )}$ & 74.05 & 74.02 & 42.19 & 84.94 & 38.12 \\
$2.2 \mathrm{H} \mathrm{( \% )}$ & 12.04 & 13.56 & 5.21 & 11.01 & 5.18 \\
$2.3 \mathrm{O}(\%)$ & 3.30 & 3.53 & 46.74 & 2.78 & 5.56 \\
$2.4 \mathrm{~N}(\%)$ & 0.32 & $<\mathrm{LOQ}$ & 1.19 & 0.58 & 0.82 \\
$2.5 \mathrm{~S}(\%)$ & 0.07 & 39,980 & 15,714 & 0.04 & 0.12 \\
$2.6 \mathrm{Calorific}$ & 38,694 & & & 43,156 & 14,085 \\
value (kJ/kg) & & & & &
\end{tabular}

Note: LOQ is Limit of Quantification $(0.01 \%)$

\section{Physical Properties for RDF Productions}

The various RDFs in this study include a plastic bag wastes-palm fronds-RDF (PP-RDF), an unused plastic bag wastes-palm fronds-RDF (UPP-RDF), a plastic bag wastes-palm fronds-cassava peels-RDF (PPC-RDF) and a plastic bag wastes-palm fronds-rubber wastes-RDF (PPR-RDF) (Fig. 8).

Table 2 shows the physical properties of RDFs such as the density, the drop shatter index and the unconfined compressive strength. The density of various RDFs is $0.50-0.69,0.57-0.65,0.56-0.73$ and $0.46-0.53 \mathrm{~g} / \mathrm{cm}^{3}$ for PP-RDF, UPP-RDF, PPC-RDF and PPR-RDF, respectively. The suitable density of RDF is $0.4-0.7$ $\mathrm{g} / \mathrm{cm}^{3}$ (Ohlsson et al., 1991). Therefore, all RDFs produced, are suitable for RDF in the briquette form. The drop shatter index is to estimate the capacity of sample to resist breakage during handling and transportation. The drop shatter index is $0.76-0.84,0.75-$ 0.93, 0.80-0.92 and 0.78-0.91 for PP-RDF, UPP-RDF, PPC-RDF and PPR-RDF, respectively. The suitable drop shatter index is ranged between 0.5 and 1.0. Therefore, all of RDF types are good quality in the briquette form.

Unconfined compressive strength test is used to measure the shearing resistance of the cohesive sample which may be undisturbed or remolded RDFs. The unconfined compressive strength is defined as the maximum unit stress obtained within the first $20 \%$ strain. The unconfined compressive strength of RDFs is $0.40-0.67,2.01-2.32,0.30$ 1.18 and $0.39-0.73 \mathrm{~kg} / \mathrm{cm} 2$ for PP-RDF, UPP-RDF, PPCRDF and PPR-RDF, respectively. The best ratio of RDF for unconfined compressive strength is all RDFs.

\section{Proximate Analysis and Ultimate Analysis for RDF Productions}

The results of proximate analysis for various RDFs show in the Table 3. The PP-RDF characteristic is $7.18 \%$ moisture content, $72.41 \%$ volatile solids, $9.24 \%$ fixed carbon and $11.16 \%$ ash. The UPP-RDF characteristic is $4.13 \%$ moisture content, $62.99 \%$ volatile solids, $7.70 \%$ fixed carbon and $25.17 \%$ ash.

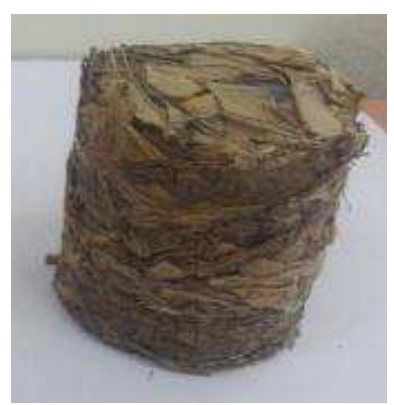

(a)

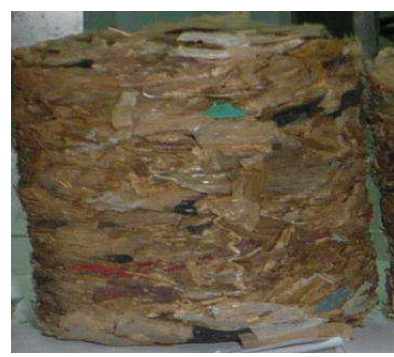

(c)

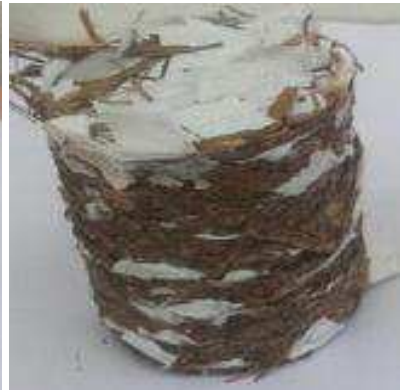

(b)

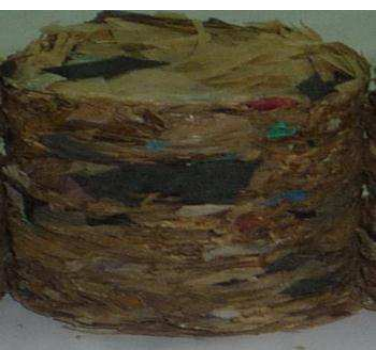

(d)
Figs. 8: Refuse Derived Fuels: (a) PP-RDF, (b) UPPRDF, (c) PPC-RDF and (d) PPR-RDF

The PPC-RDF characteristic is $0.34 \%$ moisture content, $94.85 \%$ volatile solids, $0.09 \%$ fixed carbon and $4.72 \%$ ash. The PPR-RDF characteristic is $0.26 \%$ moisture content, $94.24 \%$ volatile solids, $0.25 \%$ fixed carbon and $5.25 \%$ ash. The moisture content of all RDFs is very low. These ranges of moisture content are within the range for the gasification system application (Reed and Das, 1988). Thus, they are suitable for the combustion as a solid fuel.

The ultimate analysis gives the composition of RDF in weight percentage of carbon, hydrogen and oxygen as well as nitrogen and sulfur. Table 4 shows the ultimate analysis of RDFs from excavated plastic bag wastes. The ultimate analysis of PP-RDF contains $42.86 \% \mathrm{C}, 6.42 \% \mathrm{H}, 20.49 \% \mathrm{O}, 0.77 \% \mathrm{~N}$ and $0.06 \%$ $\mathrm{S}$. The ultimate analysis of UPP-RDF contains $41.88 \% \mathrm{C}, 6.50 \% \mathrm{H}, 24.59 \% \mathrm{O}, 0.78 \% \mathrm{~N}$ and $0.06 \% \mathrm{~S}$. 
Table 2: The physical properties for RDF productions

\begin{tabular}{|c|c|c|c|c|}
\hline Properties & PP-RDF & UPP-RDF & PPC-RDF & PPR-RDF \\
\hline Density $\left(\mathrm{g} / \mathrm{cm}^{3}\right)$ & $0.50-0.69$ & $0.57-0.65$ & $0.56-0.73$ & $0.46-0.53$ \\
\hline Drop shatter index & $0.76-0.84$ & $0.75-0.93$ & $0.80-0.92$ & $0.78-0.91$ \\
\hline $\begin{array}{l}\text { Unconfined compressive } \\
\text { strength }\left(\mathrm{kg} / \mathrm{cm}^{2}\right)\end{array}$ & $0.40-0.67$ & $2.01-2.32$ & $0.30-1.18$ & $0.39-0.73$ \\
\hline
\end{tabular}

Table 3: Proximate analysis for RDF productions

\begin{tabular}{lrccr}
\hline $\begin{array}{l}\text { Proximate } \\
\text { analysis }\end{array}$ & \multicolumn{1}{c}{ PP-RDF } & UPP-RDF & PPC-RDF & PPR-RDF \\
\hline MC (\%) & 7.18 & 4.13 & 0.34 & 0.26 \\
VS (\%) & 72.41 & 62.99 & 94.85 & 94.24 \\
FC (\%) & 9.24 & 7.70 & 0.09 & 0.25 \\
Ash (\%) & 11.16 & 25.17 & 4.72 & 5.25 \\
\hline
\end{tabular}

Table 4: Ultimate analysis for RDF productions

\begin{tabular}{lrrrr}
\hline $\begin{array}{l}\text { Ultimate } \\
\text { analysis }\end{array}$ & PP-RDF & UPP-RDF & PPC-RDF & PPR-RDF \\
\hline C (\%) & 42.86 & 41.88 & 48.95 & 47.85 \\
H (\%) & 6.42 & 6.50 & 6.70 & 6.13 \\
O (\%) & 20.49 & 24.59 & 37.88 & 39.03 \\
N (\%) & 0.77 & 0.78 & 1.02 & 0.96 \\
S (\%) & 0.06 & 0.06 & 0.17 & 0.13 \\
Cl (\%) & 0.27 & 0.30 & 0.14 & 0.07 \\
\hline
\end{tabular}

The ultimate analysis of PPC-RDF contains $48.95 \%$ C, $6.70 \% \mathrm{H}, 37.88 \% \mathrm{O}, 1.02 \% \mathrm{~N}$ and $0.17 \% \mathrm{~S}$. The ultimate analysis of PPRRDF contains $47.85 \% \mathrm{C}$, $6.13 \% \mathrm{H}, 39.03 \% \mathrm{O}, 0.96 \% \mathrm{~N}$ and $0.13 \% \mathrm{~S}$. The results show similar ultimate analysis. All RDFs provide very low of sulfur and chlorine contents. The chlorine content is $0.0027 \%, 0.0030 \%, 0.0014 \%$ and $0.0007 \%$ of PP-RDF, UPP-RDF, PPCRDF and PPRRDF, respectively. The high sulfur and chlorine contents can lead to higher emission of acidic gaseous pollutants in the combustion process (Watanabe et al., 2004). The sulfur content is found relatively low in comparison with the European standard limit of $0.4 \%$ for RDF, the chlorine contents is lower than $0.5 \%$ set in European standard (European CommissionDirectorate General Environment, 2003). Plastic bag wastes and unused plastic bag wastes should be blended with other low chlorine containing raw materials before used as RDF in order to comply with the specified limit.

The higher heating value (HHV) results from the completely direct combustion of the RDF to carbon dioxide and liquid water. The HHV of PP-RDF, UPPRDF, PPC-RDF and PPR-RDF is 5,725, 5,674, 5,548 and $5,872 \mathrm{kcal} / \mathrm{kg}$, respectively, which is slightly higher than that showed in Chiemchaisri et al. (2010). The HHV criterion for RDF is higher than $3,585 \mathrm{kcal} / \mathrm{kg}$ (Gendebien et al., 2003). Thus, the various RDFs are suitable for waste to energy. The quality of all briquette RDFs in this study is in compliance with the standards and acceptable for kiln use.

\section{Conclusion}

All binders in this study including palm fronds, cassava peels and rubber wastes are suitable to be used as a binder for plastic bag wastes RDF5 productions. However, the form of briquette RDF is the most suitable form for the plastic bag wastes. The various RDFs in this study include a plastic bag wastes-palm fronds-RDF (PP-RDF), an unused plastic bag wastes-palm frondsRDF (UPP-RDF), a plastic bag wastes-palm frondscassava peels-RDF (PPC-RDF) and a plastic bag wastes-palm fronds-rubber wastes-RDF (PPR-RDF). The all RDFs have good physical and chemical properties. The HHV of PP-RDF, UPP-RDF, PPC-RDF and PPR-RDF is 5,725, 5,674, 5,548 and 5,872 kcal $/ \mathrm{kg}$, respectively. The quality of the briquette RDFs in this study is in compliance with the standards and acceptable for kiln use. Therefore, the plastic-bag-wastes RDF in the briquette form is suitable for renewable energy. The air pollutant emission of the various RDF fuels will be investigated in the future work.

\section{Acknowledgement}

This work was supported by the Higher Education Research Promotion and the Thailand's Education Hub for Southern Region of ASEAN Countries Project Office of the Higher Education Commission (THEAC028/2015) and Air Pollution and Health Effect Research Center, Prince of Songkla University. The Authors would like to acknowledge the Sustainable Waste Management Team (SWM Team) for partial financial and equipment providing support.

\section{Author's Contributions}

Rithy Kan: Developed the hypothesis and initiated the conceptual design, contributed in experimental design, performed data analysis, interpreted the results and did the manuscript writing.

Chatchai Kungkajit: Contributed in experimental design, performed data analysis and interpreted the results.

Thaniya Kaosol: Contributed in experimental design, supervised the research and was involved in all aspect of the research. Revision and final approval. 


\section{Ethics}

This article is original and contains unpublished material. The corresponding author confirms that all of the other authors have read and approved the manuscript and no ethical issues involved.

\section{References}

Al-Salem, S.M., P. Lettieri and J. Baeyens, 2009. Recycling and recovery routes of Plastic Solid Waste (PSW): A review. Waste Management, 29: 2625-2643. DOI:10.1016/j.wasman.2009.06.004

Arena, U., F. Di Gregorio, C. Amorese and M.L. Mastellone, 2011. A techno-economic comparison of fluidized bed gasification of two mixed plastic wastes. Waste Management, 31: 1494-1504. DOI:10.1016/j.wasman.2011.02.004

Arena, U., M.L. Mastellone and F. Perugini, 2003. The environmental performance of alternative solid waste management options: A life cycle assessment study. Chemical Eng. J., 96: 207-222.

DOI: $10.1016 /$ j.cej.2003.08.019

ASTM, 2006. Standard definitions of terms and abbreviations relating to physical and chemical characteristics of refuse derived fuel. Vol. 11.04, Waste Management, Annual Book of ASTM Standards 2006, West Conshohocken: ASTM International.

Beccali, G., M. Cellura and M. Mistretta, 2001. Managing municipal solid waste: Energetic and environmental comparison among different management options. Int. J. Life Cycle Assessment, 6: 243-249. DOI: 10.1065/lca2001.02.049

Caputo, A.C. and P.M. Pelagagge, 2002. RDF production plants: II Econonics and profitability. Applied Thermal Eng., 22: 439-448. DOI: 10.1016/S1359-4311(01)00101-6

Chiemchaisri, C., B. Charnnok and C. Visvanathan, 2010. Recovery of plastic wastes from dumpsite as refuse-derived fuel and its utilization in small gasification system. Bioresource Technology, 101: 1522-1527. DOI: 10.1016/j.biortech.2009.08.061

Consonni, S., M. Giugliano and M. Grosso, 2005. Alternative strategies for energy recovery from municipal solid waste: Part A: Mass and energy balances. Waste Management, 25: 123-155. DOI: $10.1016 /$ j.wasman.2004.09.007

European Commission-Directorate General Environment, 2003. Refuse derived fuel, current practice and perspectives: Quality standards for solid recovered fuel. Report No.: CO 5087-4.
Gendebien, A., A. Leavens, K. Blackmore, A. Godley and K. Lewin et al., 2003. Refuse Derived Fuel, current practice and perspectives final report. European Commission. Report No.: CO 5087-4.

Gug, J., D. Cacciola and M.J. Sobkowicz, 2015. Processing and properties of a solid energy fuel from Municipal Waste (MSW) and recycled plastics. Waste Management, 35: 283-292. DOI: $10.016 /$ j.wasman.2014.09.031

Koukouzas, N., A. Katsiadakis, E. Karlopoulos and E. Kakaras, 2008. Co-gasification of solid waste and lignite - A case study for Western Macedonia. Waste Management, 28: 1263-1275. DOI: 10.1016/j.wasman.2007.04.011

Murphy, J.D. and E. McKeogh, 2004. Technical, economic and environmental analysis of energy production from municipal solid waste. Renewable Energy, 29: 1043-1057.

DOI: $10.1016 /$ j.renene.2003.12.002

Ohlsson, O.O., D.K. Walters and B.J. 1991. An overview of RDF Processing Systems; Current Status. Design Feature Trends. In: Refuse Derived Fuel (RDF) Quality, C. Saltiel (Ed.), Standards and Processing. Fact 13, American Society of Mechanical Engineerings, USA.

Piao, G., S. Aono, S. Mori, S. Deguchi and Y. Fujima et al., 1998. Combustion of refuse derived fuel in a fluidized bed. Waste Management, 18: 509-512. DOI: 10.1016/S0956-053X(98)00140-8

Reed, T.B. and A. Das, 1988. Handbook of biomass downdraft gasifier engine systems. Biomass Bioenergy Foundation Press, ISBN-13: 978-1890607005

Rotter, V.S., T. Kost, J. Winkler and B. Bilitewski, 2004. Material flow analysis of RDF-production processes. Waste Management, 24: 1005-1021. DOI: 10.1016/j.wasman.2004.07.015

Saifuddin, N., P. Priatharsini and S.B. Hakim, 2016. Microwave-assisted co-pyrolysis of bamboo biomass with plastic waste for hydrogen-rich syngas production. Am. J. Applied Sci., 13: 511-521. DOI:10.3844/ajassp.2016.511.521

Tchobanoglous, G., H. Theisen and S.A. Vigil, 1993. Integrated Solid Waste Management, Engineering Principles and Management Issues. McGraw-Hill Inc., New York. ISBN-13:9780071128650

Tue, K.A. and M.M. Thwe, 2013. Recycle of plastic waste and agricultural waste. Energy Res. J., 4: 24-29. DOI: 10.3844/erjsp.2013.24.29

UNEP, 2005. Solid Waste Management: Volume I, United Nations Environment Programme, ISBN: 92-807-2676-5. 
Watanabe, N., O. Yamamoto, M. Sakai and J. Fukuyama, 2004. Combustible and incombustible speciation of $\mathrm{Cl}$ and $\mathrm{S}$ in various components of municipal solid wastes. Waste Management, 24: 623-632. DOI: 10.1016/j.wasman.2004.03.003

Weber, R., T. Kupka and K. Zajac, 2009. Jet flames of a refuse derived fuel. Combustion Flame, 156: 922-927. DOI: 10.1016/j.combustflame.2008.12.011
Yaman, S., M. Sahan, H. Haykiri-Acma, K, Sesen and S. Kucukbayrak, 2001. Fuel briquettes from biomasslignite blends. Fuel Processing Technology, 72: 1-8. DOI: $10.1016 / \mathrm{S} 0378-3820(01) 00170-9$ 